\title{
Critical Success Factors for Implementing Business Intelligence Systems in Small and Medium Enterprises on the Example of Upper Silesia, Poland
}

\author{
Celina M. Olszak and Ewa Ziemba \\ University of Economics, Katowice, Poland
}

\author{
celina.olszak@ue.katowice.pl ewa.ziemba@ue.katowice.pl
}

\begin{abstract}
The main objective of this article is to identify the critical success factors (CSFs) for Business Intelligence (BI) systems implementation in small and medium enterprises (SMEs). The structure of the article is subordinated to this objective. The paper identifies the term Business Intelligence, characteristics of Business Intelligence systems, and various perspectives of their development. Then, the existing CSFs of IT projects and BI projects proposed by various authors in literature are reviewed. Next, on the basis of statistical data and literature, the role of SMEs in the economy and the barriers to their development are assessed. The obtained results allowed us to determine that one of the barriers to the SMEs development is the implementation and use of IT. Subsequently, using in-depth interviews with SMEs, the SMEs need for BI systems as well as the determinants and barriers to their implementation are recognized. Based on the findings, using critical thinking and inductive reasoning, the authors of the article along with the researched enterprises have defined CSFs that are crucial for implementing BI systems in SMEs. The results obtained may be useful for managers, policy makers, business analysts, and IT specialists in dealing with planning and implementation of BI systems in SMEs.
\end{abstract}

Keywords: Business Intelligence, critical success factors, small and medium enterprises

\section{Introduction}

Business Intelligence is the subject of an extensive discussion in the literature. The interest in this subject has increased significantly when the opinions began to appear indicating that BI systems are an important component of a modern enterprise's information infrastructure, as they contribute to its success and competitiveness (Davenport, Harris, \& Morison, 2010). They quickly became the focus of attention, not only of professionals dealing with the construction of information systems, but also managers interested in introducing new tools in order to manage enterprises

Material published as part of this publication, either on-line or in print, is copyrighted by the Informing Science Institute. Permission to make digital or paper copy of part or all of these works for personal or classroom use is granted without fee provided that the copies are not made or distributed for profit or commercial advantage AND that copies 1) bear this notice in full and 2) give the full citation on the first page. It is permissible to abstract these works so long as credit is given. To copy in all other cases or to republish or to post on a server or to redistribute to lists requires specific permission and payment of a fee. Contact Publisher@,InformingScience.org to request redistribution permission.
(Wixom \& Watson, 2010).

However, an analysis shows that many BI projects frequently fail or are not undertaken at all. The reasons mentioned, among other things, include a relatively low level of knowledge in organizations (especially SMEs) about the opportunities and benefits of BI systems, as well as about their critical success factors. 
So far, BI systems have mainly been adopted in large, multinational and international enterprises and, hence, research work on CSFs has largely been focused on them, reflecting their situations and needs. There is a lack of in-depth research on BI critical success factors in SMEs, and they are becoming an important beneficiary of BI systems. The need for a more systematic and deliberate study on the critical success factors for implementing BI in SMEs is crucial. These enterprises need to be cognizant and aware of the factors that will influence the success of a BI initiative. It is worth mentioning that the issue of BI use in SMEs is extremely important because of the role that these enterprises play in the economy. Practice shows that the use of BI systems in SMEs can be a source of competitive advantage.

Our research attempts to answer the question: What are the general CSFs for BI systems implementation in SMEs? The structure of the article is subordinated to this question. This paper identifies the term of BI, characteristics of BI systems, and various perspectives of their development. Then, the existing CSFs of IT project and BI project proposed by various authors in literature are reviewed. Next, on the basis of statistical data and literature, the role of SMEs in the economy and the barriers to their development are assessed. The obtained results allowed us to determine that one of the barriers to the SMEs development is the implementation and use of IT. Subsequently, using in-depth interviews with SMEs, the SMEs need for BI systems as well as the determinants and barriers to their implementation are identified. Based on the findings, using critical thinking and inductive reasoning, the authors of the article along with the researched enterprises have defined CSFs that are crucial for implementing BI systems in SMEs.

The results obtained may be useful for managers, policy makers, business analysts, and IT specialists in dealing with planning and implementation of BI systems in SMEs.

\section{Related Works}

\section{Business Intelligence Systems}

The role of BI systems and their influence over organizations have been subject to change. From simple, static analytical applications they have evolved into solutions that can be used in strategic planning, customer relationship management, monitoring operations, studying the profitability of products, etc. (Negash \& Gray, 2008). They are no longer regarded as a technological category only and have become the determinant of a new approach to the management of an organization (Sauter, 2010) and a new way of collecting, storing, processing, analysing, and using information (Williams \& Williams, 2007).

The term of Business Intelligence has been defined in different ways and there is no universally accepted definition of BI. Most likely, the term BI was first used in 1958 (Luhn, 1958) and was identified with the tools for data analysis (Anandarajan \& Srinivasan, 2004). Many people, however, believe that the term BI was first used as a common name for describing a concept and methodologies for improvement of business decisions using facts and information from supporting systems by Dresner in 1989 (Power, 2007).

According to Reinnschmidt and Francouise (2000), a BI system is "an integrated set of tools, technologies and programmed products that are used to collect, integrate, analyze and make data available."

With the passing of time, the term BI has been understood much more broadly, namely, as a connecting factor of different components of decision support infrastructure (Baaras \& Kemper 2008) and providing comprehensive information for policy makers (Negash, 2004). Hence, many definitions of BI systems focus on the capability of an enterprise to improve business efficiency and to achieve higher business goals. It is said that BI as a concept provides a means to obtain 
crucial information to improve strategic decisions and, therefore, plays an important role in current decision support systems (Inmon, Strauss \& Neushloss, 2008).

According to Azvine, Cui, Nauck, and Majeed (2006), BI is all about capturing, accessing, understanding, analysing, and converting one of the fundamental and most precious assets of the company, represented by the raw data, into active information in order to improve business. Wells $(2003,2008)$ understands BI very broadly and thinks that BI is the capability of an organization or enterprise to explain, plan, predict, solve problems, think in an abstract way, understand, invent, and learn in order to increase organizational knowledge, provide information for the decision-making process, enable effective actions, and support establishing and achieving business goals.

The term BI is compared to "an umbrella" that is commonly used to describe the technologies, applications, and processes for gathering, storing, accessing and analyzing data to help users to make better decisions (Davenport et al., 2010; Wixom \& Watson, 2010).

$\mathrm{BI}$ is closely linked with the issue of data warehouse. This is a key technology used to build such systems, integrating data from different sources for analytical purposes (Inmon et al., 2008). Data downloaded to a data warehouse can come from various sources: from internal information systems of an organization and from the environment, e.g., statistics, financial and investment portals, and miscellaneous databases (Wixom \& Watson, 2001, 2010). Hence it is assumed that the main tasks to be faced by BI systems include intelligent exploration, integration, aggregation, and a multidimensional analysis of data originating from various information resources (Sauter, 2010).

BI systems refer to decision making, information analysis and knowledge management, and human-computer interaction. Therefore, they are also often associated with systems such as MIS (management information systems), DSS (decision support systems), EIS (executive information systems), management support systems, and business / corporate performance management (O'Brien \& Marakas, 2007). However, it is good to remember certain, important differences between these systems. MIS focus mainly on the automation of business processes. DSS provide techniques for analyzing information to assess potential decisions. EIS present the information in an aggregate form, and their beneficiaries are top-level management executives. Whereas, the BI goal is to provide organizations with intelligence that should be used to create competitive advantage. They combine the capabilities of different systems, which previously operated independently. BI focuses on supporting a variety of business functions, using the process approach and advanced analytical techniques (Glancy \& Yadav, 2011).

BI systems may be analyzed from two perspectives: technical and business (Olszak \& Ziemba, $2003,2006,2010 \mathrm{a})$. From the technical perspective they are referred to as an integrated set of tools, technologies, and software products that are used to collect heterogenic data from dispersed sources and then to integrate and analyze data to make them commonly available. They include:

- tools to extract, transform and load data (ETL, Extraction-Transformation-Load tools) are mainly responsible for data transfer from transaction systems and Internet to data warehouses;

- data warehouses - provide place for thematic storing of aggregated and already analysed data;

- analytic tools (OLAP, On-Line Analytical Processing) - let users to access, analyse and model business problems and to share information that is stored in data warehouses;

- data mining tools - they enable to discover various patterns, generalisations, regularities and rules in data resources;

- tools for reporting and ad hoc inquiring - enable the creation and utilisation of different synthetic reports; and 
- presentation layer - applications including graphic and multimedia interfaces which task is to provide users with information in a comfortable and accessible form.

From the business (organizational) perspective, BI systems mean specific philosophy and methodology that refer to working with information and knowledge, open communication, and knowledge sharing along with the holistic and analytic approach to business processes in organizations. BI systems are assumed to be solutions that are responsible for transformation of data into information and knowledge, and they also create some environment for effective decisionmaking, strategic thinking, and acting in organizations (Negash \& Grey, 2008). The value of BI for business is predominantly expressed in the fact that such systems cast some light on information that may serve as the basis for carrying out fundamental changes in a particular enterprise, i.e., establishing a new co-operation, acquiring new customers, creating new markets, offering products to customers (Chaudhary, 2004; Olszak \& Ziemba, 2004).

It should be noted that the processes are also a very important part of BI (Wixom \& Watson 2010). For example, there are processes for extracting, loading, and storing data; maintaining metadata for IT and users; and prioritizing BI projects. Some of these processes are the responsibility of the BI staff, while others are the joint responsibility of the BI staff and the business units.

A detailed analysis of the literature shows that there is no universal definition of BI. For the purposes of this study it is assumed that BI is a broad category covering technology, applications, and processes responsible for the collection, storage, data access, and analysis that can help users in making more effective decisions (Wixom \& Watson 2010).

\section{Critical Success Factors}

The complexity and versatility of modern BI systems mean that success in their implementation requires referring to a solid methodical foundation and proven scientific theories. It seems that the theory of critical success factors gives good basis for stating what criteria should be followed during their implementation.

In the literature there are several definitions of critical success factors (CSFs) (Amberg, Fischl \& Wiener, 2005). For example Rockart (1979), presenting one of the most frequently cited definitions, uses ideas from Daniel (1961) as well as Anthony, Dearden and Vancil (1972) in defining CSFs as "the limited number of areas in which results, if they are satisfactory, will ensure successful competitive performance for the organization". Consequently, the author stresses, that these particular areas of activity should be constantly and carefully managed by an enterprise if the business is to survive and flourish. The author has identified four primary sources of CSFs:

- industry-based factors;

- competitive strategy, industry position, and geographical factors;

- environmental factors; and

- temporal factors.

In the opinion of Leidecker and Bruno (1987), CSFs should account for the properties, terms or variables that can, in an important way, influence the success of an enterprise establishing its position in a particular industry given that the variables, existing terms, and properties of such an industry are well preserved, sustained or managed; moreover, recognising and classifying them can help to identify the characteristics and the range of resources that must be at the disposal of a project team to focus on primary matters (Greene \& Loughridge, 1996).

In the 1970s and 1980s many authors published a list of critical success factors in relation to specific issues and types of activities. Table 1 summarizes (the most common and recognized as the most important) critical success factors of projects identified by various authors. 
Critical success factors differ among industries and for individual enterprises within a particular industry. They can be strategic, managerial, or operational and are defined mainly in terms of three aspects: organizational, industry and environmental. They can exist at the corporate level, as well as at the sub-levels of a division, plant, and department. Sometimes it is even necessary to consider the CSFs of individual employees (Turban, McLean, \& Wetherbe, 2001).

Table 1: CSFs according to different authors

\begin{tabular}{|c|c|c|c|c|c|c|}
\hline $\begin{array}{c}\text { Martin } \\
\text { (1976) }\end{array}$ & Locke (1984) & $\begin{array}{l}\text { Cleland and } \\
\text { King (1983) }\end{array}$ & $\begin{array}{c}\text { Sayles \& } \\
\text { Chandler } \\
(1971)\end{array}$ & $\begin{array}{l}\text { Baker, Mur- } \\
\text { phy \& Fisher } \\
(1983)\end{array}$ & $\begin{array}{c}\text { Pinto \& } \\
\text { Slevin (1989) }\end{array}$ & $\begin{array}{c}\text { Morris \& } \\
\text { Hough } \\
\text { (1987) }\end{array}$ \\
\hline $\begin{array}{l}\text { Define goals } \\
\text { Select project } \\
\text { organizational } \\
\text { philosophy } \\
\text { General man- } \\
\text { agement sup- } \\
\text { port } \\
\text { Organize and } \\
\text { delegate au- } \\
\text { thority } \\
\text { Select project } \\
\text { team } \\
\text { Allocate suf- } \\
\text { ficient re- } \\
\text { sources } \\
\text { Provide for } \\
\text { control and } \\
\text { information } \\
\text { mechanisms } \\
\text { Require plan- } \\
\text { ning and re- } \\
\text { view }\end{array}$ & $\begin{array}{l}\text { Make project } \\
\text { commitments } \\
\text { known } \\
\text { Project au- } \\
\text { thority from } \\
\text { the top } \\
\text { Appoint } \\
\text { competent } \\
\text { project man- } \\
\text { ager } \\
\text { Set up com- } \\
\text { munications } \\
\text { and proce- } \\
\text { dures } \\
\text { Set up control } \\
\text { mechanisms, } \\
\text { schedules, } \\
\text { etc. } \\
\text { Progress } \\
\text { meetings }\end{array}$ & $\begin{array}{l}\text { Project sum- } \\
\text { mary } \\
\text { Operational } \\
\text { concept } \\
\text { Top manage- } \\
\text { ment support } \\
\text { Financial sup- } \\
\text { port } \\
\text { Logistic re- } \\
\text { quirements } \\
\text { Facility support } \\
\text { Market intelli- } \\
\text { gence (who is } \\
\text { the client) } \\
\text { Project sched- } \\
\text { ule } \\
\text { Executive de- } \\
\text { velopment and } \\
\text { training } \\
\text { Manpower and } \\
\text { organization } \\
\text { Information and } \\
\text { communication } \\
\text { channels } \\
\text { Project review }\end{array}$ & $\begin{array}{l}\text { Project } \\
\text { manager's } \\
\text { compe- } \\
\text { tence } \\
\text { Schedul- } \\
\text { ing } \\
\text { Control } \\
\text { systems } \\
\text { and re- } \\
\text { sponsibili- } \\
\text { ties } \\
\text { Monitor- } \\
\text { ing and } \\
\text { feedback } \\
\text { Continu- } \\
\text { ing in- } \\
\text { volvement } \\
\text { in the } \\
\text { project }\end{array}$ & $\begin{array}{l}\text { Clear goals } \\
\text { Goal commit- } \\
\text { ment of project } \\
\text { team } \\
\text { On-site project } \\
\text { manager } \\
\text { Adequate pro- } \\
\text { ject team capa- } \\
\text { bility } \\
\text { Adequate fund- } \\
\text { ing to comple- } \\
\text { tion } \\
\text { Accurate initial } \\
\text { cost estimates } \\
\text { Minimum start- } \\
\text { up difficulties } \\
\text { Planning and } \\
\text { control tech- } \\
\text { niques } \\
\text { Task (vs. social } \\
\text { orientation) } \\
\text { Absence of } \\
\text { bureaucracy }\end{array}$ & $\begin{array}{l}\text { Top manage- } \\
\text { ment support } \\
\text { Client consul- } \\
\text { tation } \\
\text { Personnel } \\
\text { recruitment } \\
\text { Technical } \\
\text { task } \\
\text { Client ac- } \\
\text { ceptance } \\
\text { Monitoring } \\
\text { and feedback } \\
\text { Communica- } \\
\text { tion } \\
\text { Trouble- } \\
\text { shooting } \\
\text { Characteris- } \\
\text { tics of the } \\
\text { project team } \\
\text { leader } \\
\text { Power and } \\
\text { politics } \\
\text { Environment } \\
\text { events } \\
\text { Urgency }\end{array}$ & $\begin{array}{l}\text { Project } \\
\text { objectives } \\
\text { Technical } \\
\text { uncertainty } \\
\text { innovation } \\
\text { Politics } \\
\text { Communi- } \\
\text { ty in- } \\
\text { volvement } \\
\text { Schedule } \\
\text { duration } \\
\text { urgency } \\
\text { Financial } \\
\text { contract } \\
\text { legal prob- } \\
\text { lems } \\
\text { Implement } \\
\text { problems }\end{array}$ \\
\hline
\end{tabular}

Source: (Belassi \& Tukel, 1996).

In the literature of the later period, lists of critical success factors of projects can also be found, including IT projects. In the area of information technology systems the use of CSFs is valuable in helping to align new systems with business objectives. CSFs are these factors that determine whether business objectives are achieved. Fortune and White (2006) published a list of critical success factors of projects based on 63 publications. These factors are listed in order of their frequency of quotation (Table 2).

On the other hand, in the Standish Group report, CSFs were mentioned in the order in which they affect the success of the project (The Standish Group, 2001):

- management support;

- users' involvement;

- experience of a project manager;

- clearly defined business objectives;

- minimized the scope of the project; 
- standardization of application infrastructure;

- stable;

- solution base;

- formal methodology; and

- reliable estimate.

Table 2: CSFs - the number of quotations in the literature

\begin{tabular}{|c|c|}
\hline Critical success factors & Number of quotations \\
\hline Support from senior management & 39 \\
\hline Clear realistic objectives & 31 \\
\hline Strong/detailed plan kept up to date & 29 \\
\hline Good communication/feedback & 27 \\
\hline User/client involvement & 24 \\
\hline Skilled/suitably qualified sufficient staff/team & 20 \\
\hline Effective change management & 19 \\
\hline Competent project manager & 19 \\
\hline Strong business case/sound basis for project & 16 \\
\hline Sufficient/well allocated resources & 16 \\
\hline Good leadership & 15 \\
\hline Proven/familiar technology & 14 \\
\hline Realistic schedule & 14 \\
\hline Risks addressed/assessed/managed & 13 \\
\hline Project sponsor/champion & 12 \\
\hline Effective monitoring/control & 12 \\
\hline Adequate budget & 11 \\
\hline Organizational adaptation/culture/structure & 10 \\
\hline Good performance by suppliers/contractors/consultants & 10 \\
\hline Planned close down/review/acceptance of possible failure & 9 \\
\hline Training provision & 7 \\
\hline Political stability & 6 \\
\hline $\begin{array}{l}\text { Correct choice/past experience of project management methodolo- } \\
\text { gy/tools }\end{array}$ & 6 \\
\hline Environmental influences & 6 \\
\hline Past experience (learning from) & 5 \\
\hline $\begin{array}{l}\text { Project size (large)/level of complexity (high)/number of people } \\
\text { involved (too many)/duration (over } 3 \text { years) }\end{array}$ & 4 \\
\hline Different viewpoints (appreciating) & 3 \\
\hline
\end{tabular}

Source: (Fortune \& White, 2006)

Another division of critical success factors was suggested by Kwak (2002), focusing, among the other things, on the critical factors of projects failure (Table 3). 
Table 3: 10 CSFs 10 critical factors of failure of projects by Y.H. Kwak

\begin{tabular}{|c|c|}
\hline Factors & Description \\
\hline Political & $\begin{array}{l}\text { Inconsistency in policies, laws and regulations, and political instability. Several } \\
\text { associated factors that may prompt political challenge to the project are: } \\
\text { - political takeover or military coup; } \\
\text { - war or revolution; } \\
\text { - allegations of corruption causing government resignation; and } \\
\text { - nationalization of assets with or without adequate compensation. }\end{array}$ \\
\hline Legal & $\begin{array}{l}\text { Legal factors include: } \\
\text { - unexpected changes in government policies pertinent to laws and regulations } \\
\text { and currency conversion; } \\
\text { - absence of appropriate regulatory systems; } \\
\text { - rates and methods of taxation including customs, royalties, convertibility of } \\
\text { currency; } \\
\text { - role of local courts in arbitration; and } \\
\text { - the methods by which electricity tariffs are set and approved. }\end{array}$ \\
\hline Cultural & $\begin{array}{l}\text { Various socio-cultural background of the parties involved, various thinking pro- } \\
\text { cesses. }\end{array}$ \\
\hline Technical & $\begin{array}{l}\text { Several associated factors that may prompt technical challenge to the project are: } \\
\text { - design; } \\
\text { - engineering; } \\
\text { - procurement; and } \\
\text { - construction, equipment installation and operation of the equipment and its } \\
\text { compatibility with accomplishment of project objectives. }\end{array}$ \\
\hline $\begin{array}{l}\text { Managerial/ or- } \\
\text { ganizational }\end{array}$ & $\begin{array}{l}\text { Managerial or organizational factors refer to inadequate or ineffective manage- } \\
\text { ment of the project by project sponsor or project management agency. The events } \\
\text { in managerial factors include the following: } \\
\text { - inadequate communication; } \\
\text { - unclear objectives; } \\
\text { - too optimistic goals in relation to project cost and schedule; } \\
\text { - lack of project sponsorship; } \\
\text { - unclear lines of responsibility, authority, and accountability; } \\
\text { - slow and cumbersome decision-making process; } \\
\text { - lack of training of the local staff for sustainability; and } \\
\text { - lack of end-user participation. }\end{array}$ \\
\hline Economical & $\begin{array}{l}\text { Economic factors refer to the issues influencing the economic feasibility of the } \\
\text { project including the changes in domestic economic conditions of the recipient } \\
\text { country or inaccurate project development plan due to unpredictable economic } \\
\text { conditions. }\end{array}$ \\
\hline Environmental & $\begin{array}{l}\text { Environmental factors refer to issues in conflict with established environmental } \\
\text { regulations of the recipient country. This comprises pollution related issues such } \\
\text { as noise, air pollution, water pollution, and visual disturbances and those related to } \\
\text { natural resources such as unsustainable use of natural resources including miner- } \\
\text { als, water, land, and flora and fauna. }\end{array}$ \\
\hline Social & $\begin{array}{l}\text { Hostility due to religion, customs, and ethnicity of the project participants: } \\
\text { - social uprising or riots due to ethnicity or polarization of social strata; } \\
\text { - security of the stakeholders; } \\
\text { - overestimation of capacity of the beneficiaries; and } \\
\text { - resistance of the beneficiaries to new social values and standards or to absorb } \\
\text { the effects of economic change or new technology. }\end{array}$ \\
\hline
\end{tabular}




\begin{tabular}{|c|c|}
\hline Factors & Description \\
\hline Corruption & $\begin{array}{l}\text { Factors which enable corruption include: } \\
\text { - state agencies and politicians that implement projects; } \\
\text { - lenders that may favour some contractors; } \\
\text { - the delegation of architects, engineers, supervisors, and consultants responsible } \\
\text { for each project; } \\
\text { - panels inspecting and accepting finished projects; } \\
\text { - contractors who are ready to buy projects with bribes; and } \\
\text { - laws and regulations that can be misinterpreted to favour any parties. }\end{array}$ \\
\hline Physical & $\begin{array}{l}\text { Natural disaster (e.g. fires, floods, drought, lightning, typhoon, earthquake), wars, } \\
\text { hostilities, military coups, civil strife, and acts of terrorism. }\end{array}$ \\
\hline
\end{tabular}

Source: (Kwak, 2002).

Several research methods can be used in order to identify the relevant CSFs, and they comprise the analysis of relevant literature, case studies, Delphi technique, group interviews, multivariate analysis, questionnaires, scenario analysis, and structured interviews (Turban et al., 2001). The CSF approach involves a series of interviews conducted in two or three sessions. In the first session, the manager is queried about his or her goals and the CSFs that underline those goals. At this stage a considerable discussion may be required to ensure that the analyst thoroughly understands the interrelationships between the goals and CSFs. Every effort is made to combine or eliminate similar CSFs, and an initial set of performance measures is developed. The second session is a review of the first. It primarily focuses on identification of specific performance measures and possible reports. Additional sessions are held as necessary to obtain agreement on the CSF measures and the reports for tracking them. The reports and related information systems required to provide them are then designed by the IS group (Turban et al., 2001):

- What objectives are central to your organization?

- What critical success factors are essential to meet these objectives?

- What decisions or actions are key to these critical success factors?

- What variables underline these decisions, and how are they measured?

- What information systems can supply these measures?

Identification of critical success factors is important in the process of IT project management, especially BI project. Taking action in order to ensure occurrence of some characteristics or events affecting the success of the project while minimizing negative impacts, contributes to the success of the project. The knowledge of the critical success factors is important in planning activities as to achieve the objective of the project. But it is not the rule, that taking into account all factors will bring a success.

\section{Critical Success Factors for BI}

There are already a number of studies on BI success factors (Scholtz, Schieder, Kurze, Gluchowski \& Boehringer, 2010). In the context of Business Intelligence systems, CSFs can be perceived as a set of tasks and procedures that should be addressed in order to ensure BI systems accomplishment. These tasks and procedures would either to be fostered, if they had already occurred, or be worked out, if they were nonexistent.

It is generally believed that the implementation of a $\mathrm{BI}$ system is not a conventional applicationbased on an IT project (such as an operational or transactional system), which has been the focus of many CSF studies. Instead, it shares similar characteristics with other infrastructural projects such as an enterprise resourcing planning systems implementation. That is, implementing a BI system is not a simple activity entailing merely the purchase of a combination of software and 
hardware; rather, it is a complex undertaking requiring appropriate infrastructure and resources over a lengthy period (Moss \& Atre, 2003; Yeoh \& Koronios, 2010). BI system implementation is viewed as an organic cycle that evolves over time.

Hence, some authors identify CSFs for BI in the dimensions of organization, environment, and project planning. They find especially strong support for organizational factors (Hwang, Ku, Yen $\&$ Cheng, 2004). In addition, earlier works discovered the importance of various issues: technical (Wixom \& Watson, 2001) as well as personal, educational, and business.

Ariyachandra and Watson (2006), analyzing CSFs for BI implementation, take into account two key dimensions: process performance (i.e., how well the process of a BI system implementation went), and infrastructure performance (i.e., the quality of the system and the standard of output). Process performance can be assessed in terms of time-schedule and budgetary considerations. Whereas infrastructure performance is connected with the quality of system and information as well as this system use.

According to Yeoh and Koronios (2010), CSFs can be broadly classified into three dimensions: organisation, process, and technology. Organizational dimension includes such elements as committed management support and sponsorship, a clear vision, and a well-established business case. In turn, the process dimension includes business-centric championship and balanced team composition, business-driven and interactive development approach and user-oriented change management. Technological dimension regards such elements as business-driven, scalable and flexible technical framework, and sustainable data quality and integrity.

Table 4 summarizes the critical success factors for BI system implementation which are mentioned in the literature.

Table 4: CSFs for BI implementation by various authors

\begin{tabular}{|c|c|c|c|}
\hline Eckerson (2005) & Wise (2007) & Imhof (2004) & Others \\
\hline $\begin{array}{l}\text { Support all users } \\
\text { via integrated BI } \\
\text { suites } \\
\text { Conforms to the } \\
\text { way users work } \\
\text { Integrates with } \\
\text { desktop and op- } \\
\text { erational applica- } \\
\text { tions } \\
\text { Delivers action- } \\
\text { able information } \\
\text { Foster rapid de- } \\
\text { velopment } \\
\text { Provide a robust, } \\
\text { extensible plat- } \\
\text { form }\end{array}$ & $\begin{array}{l}\text { Make project } \\
\text { Identifying the } \\
\text { business problem } \\
\text { Determining the } \\
\text { expectations of } \\
\text { use } \\
\text { Understanding } \\
\text { delivery of data } \\
\text { Rolling out of } \\
\text { training initia- } \\
\text { tives } \\
\text { Choosing a ver- } \\
\text { tical - or hori- } \\
\text { zontal based } \\
\text { solution }\end{array}$ & $\begin{array}{l}\text { A dependable } \\
\text { architecture } \\
\text { Strong part- } \\
\text { nership be- } \\
\text { tween the } \\
\text { business } \\
\text { community } \\
\text { and IT } \\
\text { A different } \\
\text { kind of meth- } \\
\text { odology } \\
\text { Well-defined } \\
\text { business prob- } \\
\text { lems } \\
\text { A willingness } \\
\text { to accept } \\
\text { change }\end{array}$ & $\begin{array}{l}\text { Define the problem clearly - avoid scope } \\
\text { creep (Watson, Fuller \& Ariyachandra, 2004) } \\
\text { Identify user's specific issues and needs - } \\
\text { solve their problems (Watson et al., 2004) } \\
\text { Understand the underlying data issues - BI is } \\
\text { not just software (Olszak \& Ziemba, 2006) } \\
\text { Select the appropriate toolset - look for fast, } \\
\text { easy, lightweight and low cost application } \\
\text { (Salmeron \& Herrero, 2005) } \\
\text { Build for flexibility and responsiveness - } \\
\text { know that users will require changes early on } \\
\text { (Salmeron \& Herrero, 2005) } \\
\text { Leverage existing staff - eliminate solutions } \\
\text { that require new staff and/or consultants } \\
\text { (Wixom \& Watson, 2001) } \\
\text { Lead from the top - leverage your authority } \\
\text { and executive buy-in (Wixom \& Watson, } \\
\text { 2001) }\end{array}$ \\
\hline
\end{tabular}

Sources: (Eckerson, 2005; Imhof, 2004; Olszak \& Ziemba, 2006; Salmeron \& Herrero, 2005; Watson, Fuller, \& Ariyachandra, 2004; Wise, 2007; Wixom \& Watson, 2001) 
According to Williams and Williams (2007), common mistakes that are made while establishing and managing BI programs are:

- using ad hoc practices to select and fund BI projects;

- providing inadequate governance for the BI program management;

- establishing de facto program governance based on the initial BI project;

- failing to strategically position BI in the business organization; and

- not providing adequate resources and funding for supporting efforts needed for a successful BI initiative.

However, some results might not be adoptable for the special case of SMEs (Hwang et al., 2004; Scholz et al., 2010). B. Bergeron (2000) reports similar findings and suggests that conventional BI systems, which are focused on large organizations, would not meet the needs of SMEs. Hence, identifying CSFs for BI systems implementation in SMEs is becoming an important task.

\section{SMEs Role in the Economy and Barriers to Their Development}

SMEs play a major economic and social role and, therefore, are a source of economic development (European Commission, 2011; "Fostering Entrepreneurship", 2004; "Highlights from", 2004; Olszak \& Ziemba, 2008). The European Commission defines a Small and Medium Enterprise as an organisation that has fewer than 250 employees or its turnover is less than or equals $€$ 50 million, alternatively, its balance sheet total is less than or equals $€ 43$ million. An enterprise, where at least one of the above mentioned indicators is higher, is classified as a large enterprise (European Union, 2003).

SMEs are often referred to as the backbone of the European economy, providing a potential source for jobs and economic growth. SMEs directly contribute to the value added employment. Thus it may suggest a positive correlation between labour productivity and enterprise size class. This is confirmed by the Eurostat's data in Table 5.

Table 5: Turnover and value added of the non-financial business economy by size class

\begin{tabular}{|l|l|r|r|r|}
\hline \multicolumn{1}{|c|}{ Characteristics } & \multicolumn{1}{c|}{ Unit } & \multicolumn{1}{c|}{ SMEs } & \multicolumn{1}{c|}{ Large } & \multicolumn{1}{c|}{ Total } \\
\hline Turnover & EUR bln & 678 & 237098 & 1169 \\
\hline Turnover per enterprise & EUR in 1000s & 9163 & 7959 & 17122 \\
\hline Production value & EUR bln & 3547 & 2579 & 6126 \\
\hline Value added at factor cost & EUR bln & 89947 & 43414 & 133362 \\
\hline Number of persons employed & in 1000s & 20709 & 43 & 20752 \\
\hline Number of enterprises & in 1000s & 39 & 59 & 46 \\
\hline Labour productivity & $\begin{array}{l}\text { EUR in 1000s/occupied } \\
\text { person }\end{array}$ & 58 & 42 & 100 \\
\hline Turnover & $\%$ & 54 & 46 & 100 \\
\hline Production value & $\%$ & 67 & 33 & 100 \\
\hline Number of persons employed & $\%$ & 100 & 0 & 100 \\
\hline Number of enterprises & $\%$ & & & \\
\hline
\end{tabular}

Source: (European Commission, 2010a).

In Poland SMEs make up approximately $99 \%$ of all business entities and employ over $67 \%$ of the vocationally active Polish citizens. SMEs participate in generation of about $51 \%$ of the value added. The structure and main data concerning SMEs in Poland are presented in Table 6. 
Table 6: SMEs in Poland

\begin{tabular}{|l|r|r|r|r|r|r|}
\hline \multirow{2}{*}{} & \multicolumn{2}{|c|}{ Enterprises } & \multicolumn{2}{c|}{ Employment } & \multicolumn{2}{c|}{ Value added } \\
\cline { 2 - 7 } & \multicolumn{1}{|c|}{ Number } & \multicolumn{1}{c|}{ Share } & Number & \multicolumn{1}{c|}{ Share } & Billion $€$ & Share \\
\hline SMEs & 1562644 & $99.8 \%$ & 5879606 & $68.9 \%$ & 81 & $51.7 \%$ \\
\hline Large & 3105 & $0.2 \%$ & 2654220 & $31.1 \%$ & 75 & $48.3 \%$ \\
\hline Total & 1565749 & $100 \%$ & 8533826 & $100 \%$ & 156 & $100 \%$ \\
\hline
\end{tabular}

Source: (European Commission, 2010b).

In spite of SMEs' importance, generally enterprises and their products cannot meet the competitive requirements of many regional markets or the global market (Stimson, Stough, \& Roberts, 2006; Watson, 2010). Some studies show that most of the SMEs cannot conduct costly, long term research on new products and technologies. They rely on external projects, technical solutions, know-how, technologies, patents, etc. Nevertheless, it does not mean that new technically advanced products are not created by some SMEs (Czinkota, Ronkainen, \& Moffett, 2008). Furthermore, some small and mid-sized enterprises can effectively introduce their innovative products into highly competitive markets (Skowronek-Mielczarek, 2007).

Many authors point to the fact that the limitation in SMEs development translates into the difficulties in IT implementation (Arendt, 2008; Enzenhofer \& Chroust, 2001; Estrin, Foreman, \& Garcia, 2003; Olszak \& Ziemba, 2010b, 2011a, 2011b; Roztocki \& Weistroffer, 2008, Thong \& Yap 1997; Wielicki \& Arendt, 2010). Enzenhofer and Chroust (2001) list internal barriers to IT adoption that included unstructured procedures for analyzing SME needs, vague implementation practices, difficulties in identifying appropriate systems, difficulties understanding vendor systems, and excessive time needed to make IT decisions. The typical SME owner or a manager is too busy running the enterprise to learn about advanced software-based tools and technologies, much less engage in the decision-making processes required to implement them (Thong \& Yap, 1997). Moreover, managers select IT equipment basing their choices on cost, rather than its capability or compatibility with the organisation. In turn, the employees may lack the skills, experience, or resources necessary to select, adopt, or implement software tools. The research of TIDE (The Technology Insertion Demonstration and Evaluation) (on 200 small enterprises) indicates that $80 \%$ of the barriers to technology adoption were non-technical (Estrin et al., 2003). These barriers include management's tendency to view software as an expense rather than as a strategic asset and they have the attitude that advanced technologies are not required or cost-effective and the fear that technology would decrease productivity, rather than increase it.

The literature shows, that SMEs lack chief assets that large enterprises have, namely, the ability to build extensive sales network and the ease of obtaining capital or a recognizable brand. Wishing to stay in business they have to compete in a different way. Among the numerous initiatives that must be undertaken by SMEs, the studied enterprises mentioned initiatives associated with the use of IT. It is necessary to increase innovativeness and competitiveness of the economy by means of IT implementation. It is possible to provide much evidence confirming that an enterprise that makes IT-oriented investments obtains substantial profits. Unfortunately, information technology related solutions are mainly oriented at large enterprises and corporations. Putting the latest information technology related solutions into practice of SMEs is frequently much delayed in comparison with large enterprises or does not happen at all. As a result, SMEs are not as competitive in the market as large enterprises and their development is questionable. Such a situation affects the whole economy and social relations of each country, and they mainly result from in- 
sufficient knowledge and experience of SMEs as far as implementation of the latest information and computer technologies is concerned.

\section{Research Methodology}

The main objective of this article is to identify the critical success factors for BI systems implementation in SMEs. Attaining it was connected with a partial implementation of the four objectives, namely:

- determining the demand for BI systems in SMEs;

- identifying the determinants and barriers to the implementation of BI system in SMEs; and

- identifying the CSFs for the BI system implementation in SMEs.

In this study we used an analysis of static data and literature, in-depth interviews as well as critical thinking and inductive inference (Table 7).

\begin{tabular}{|c|c|c|c|}
\hline \multicolumn{4}{|c|}{ Table 7: The research methods used in the studies } \\
\hline $\begin{array}{l}\text { Purpose of } \\
\text { Research }\end{array}$ & $\begin{array}{l}\text { Research } \\
\text { Methods }\end{array}$ & $\begin{array}{c}\text { Interview's Ques- } \\
\text { tions }\end{array}$ & Research Group \\
\hline $\begin{array}{l}\text { Determining } \\
\text { the demand for } \\
\text { BI systems in } \\
\text { SMEs }\end{array}$ & $\begin{array}{l}\text { In-depth inter- } \\
\text { view }\end{array}$ & $\begin{array}{l}\text { List the most re- } \\
\text { quirements for BI } \\
\text { systems, please }\end{array}$ & $\begin{array}{l}\text { 20 SMEs from Upper Silesia, Poland: } \\
\text { - which have implemented or are in the } \\
\text { process of implementation of BI systems; } \\
\text { and } \\
\text { - which were represented by IT profession- } \\
\text { als, business analysts and owner-managers }\end{array}$ \\
\hline $\begin{array}{l}\text { Identifying the } \\
\text { determinants } \\
\text { and barriers to } \\
\text { BI system im- } \\
\text { plementation } \\
\text { of SMEs }\end{array}$ & $\begin{array}{l}\text { In-depth inter- } \\
\text { view }\end{array}$ & $\begin{array}{l}\text { List the determi- } \\
\text { nants of BI systems } \\
\text { implementation, } \\
\text { please } \\
\text { List the barriers of } \\
\text { BI systems imple- } \\
\text { mentation, please }\end{array}$ & $\begin{array}{l}\text { 20 SMEs from Upper Silesia, Poland: } \\
\text { - which have implemented or are in the } \\
\text { process of implementation of BI systems; } \\
\text { and } \\
\text { - which were represented by IT profession- } \\
\text { als, business analysts and owner-managers }\end{array}$ \\
\hline $\begin{array}{l}\text { Identifying } \\
\text { CSFs for BI } \\
\text { system imple- } \\
\text { mentation in } \\
\text { SMEs }\end{array}$ & $\begin{array}{l}\text { Critical think- } \\
\text { ing, inductive } \\
\text { reasoning, in- } \\
\text { depth inter- } \\
\text { view }\end{array}$ & $\begin{array}{l}\text { Choose the most } \\
\text { significant CSFs } \\
\text { for BI systems im- } \\
\text { plementation, } \\
\text { please }\end{array}$ & $\begin{array}{l}\text { 20 SMEs from Upper Silesia, Poland: } \\
\text { - which have implemented or are in the } \\
\text { process of implementation of BI systems; } \\
\text { and } \\
\text { - which were represented by IT profession- } \\
\text { als, business analysts and owner-managers }\end{array}$ \\
\hline
\end{tabular}

The study was conducted in stages in accordance with the defined objectives. The results obtained at the individual stages of research were the basis for the completion of later stages. The first stage of the study comprised an in-depth interview conducted in 20 SMEs from the Upper Silesia and an analysis of a demand for BI systems in SMEs. The obtained results showed (confirmed) that enterprises recognize the need to implement BI systems. This fact inspired us to undertake the third stage of research. This stage was to identify determinants of and barriers to implementation of the BI in SMEs. The study was conducted using in-depth interviews. These interviews were conducted in a group of 20 SMEs from the Upper Silesia (the same enterprises that were studied in the second stage). Based on the findings, using critical thinking and inductive reasoning, the authors of the article along with the studied companies, have defined CSFs that are crucial for implementing BI systems in SMEs. 
All studies were conducted in 2010 and covered SMEs in the region of Upper Silesia in Poland. The region of Upper Silesia was chosen because of its rapid economic development. It is also characterised by the greatest density of population in Poland and many SMEs representing commerce, production, and services. Numerous IT enterprises also operate here. 200 enterprises were invited to participate in the research. Unfortunately, only approximately $10 \%$ of invited enterprises responded positively and then agreed to participate in the research. Refusals were not justified and resulted mainly from time related constraints of individuals who were competent enough to provide valuable information. Enigmatic refusals gave the impression that potential respondents wished to avoid discussion about crucial business topics that were not thoroughly recognised by their enterprises. Answers were primarily provided by owner-managers, business analysts, and IT professionals who represented enterprises from commerce (10 enterprises), services ( 7 enterprises), and consulting (3 enterprises).

This paper presents and discusses the findings, as well as puts forward recommendations for further research. It will be of particular interest to those researchers and practitioners who are studying, providing consultancy services, and planning or implementing BI systems.

\section{Findings}

\section{The Demand for BI Systems in SMEs and the Diagnosis of BI Systems Market for SMEs}

SMEs are increasingly interested in the support of BI systems (20 enterprises), which would improve their competitiveness on the market and better management of information resources.

These are proved by the statements and opinions of owner-managers and business analysts from surveyed SMEs, such as:

- $\quad$ "small and medium enterprises need BI as well as large enterprises; in our enterprises, as in large enterprises, there is a need for fast and accurate assessment of market needs, effective discovering of market niches and avoidance of unnecessary costs";

- "quick decision-making in our enterprise gives a chance to overtake the competition, it is possible when the managers have free access to business information, and it is the result of analysis of massive amounts of data; such analyses are well performed by BI systems";

- "along with the development of computerization and the increasing amount of available data, an adequate reporting and analytical support becomes a critical element in SMEs";

- $\quad$ in order to maintain a competitive advantage it became a must to implement BI system in our enterprises; a huge amount of processed data meant that the waiting time for needed information was getting longer; a large number of spreadsheets linked with complex formulas, have forced a greater specialization in the field of information technology than analytical one; BI systems took over time-consuming data collection and processing, and workers are engaged in business operations, not in seeking and analyzing data";

- $\quad$ "with the aim to keep our offer competitive we must take decisions quickly and plan promotions, and ensure constant availability of offered products, all of our decisions are based on a careful analysis of sales data that we collect on an ongoing basis from the BI system; the result of analytical system implementation is the increase of sales margins, profit growth, full availability of goods, which the client seeks"; and

- "every day I start work by looking at the analytical reports and according to what I read from them, I set up an action plan for the enterprise, review the actions to date, designate targets". 
The owner-managers and business analysts confirm that SMEs have begun to notice that data analysis allows them to achieve a competitive advantage. Thanks to it, it is easier to react to the changes occurring in the organisation and its environment, stand up to high costs and strong competition, and make business decisions based on real, current, and complete information.

Historically, the large enterprises were the first to use BI systems and technologies such as data warehouses, OLAP, and data mining. Recently, however, it can be noted that the offer of BI systems is increasingly being directed towards SMEs. BI systems are equipped with various functions related to reporting and analyzing data for SMEs. Most of them have a modular design, allowing users to purchase the basic functionalities and their development according to changing needs in the future. BI systems offered to SMEs are relatively simple in implementation. Their implementation time takes several days and not, as until recently, a few months. BI systems for SMEs are also easy to maintain. They do not require complicated and costly maintenance by specialists. The intuitive interface enables the use of BI technology without lengthy training. They can be successfully used by beginners and advanced users. It is clearly noticeable that the manufacturers and suppliers of BI systems adapt them to the needs of smaller enterprises. On the Polish market the BI systems for SMEs are offered by domestic and international enterprises. The known systems of this class include Comarch OPTIMA, SAP BusinessObjects EDG, TETA Business Intelligence, Atlas, ExpressBI, and Oracle Business Intelligence Standard Edition One ("BI i Controlling", 2011).

\section{Determinants and Barriers to the BI Implementation in SMEs}

The interviews with the owner-managers, business analysts, and IT specialists from 20 enterprises in the SME sector that have implemented or are in the process of implementing BI systems have allowed us to identify the determinants and barriers to BI systems implementation. The determinant that plays the largest role in the BI system implementation in SMEs is the price of the BI system and its implementation. This was confirmed by 18 surveyed enterprises. Additional de-

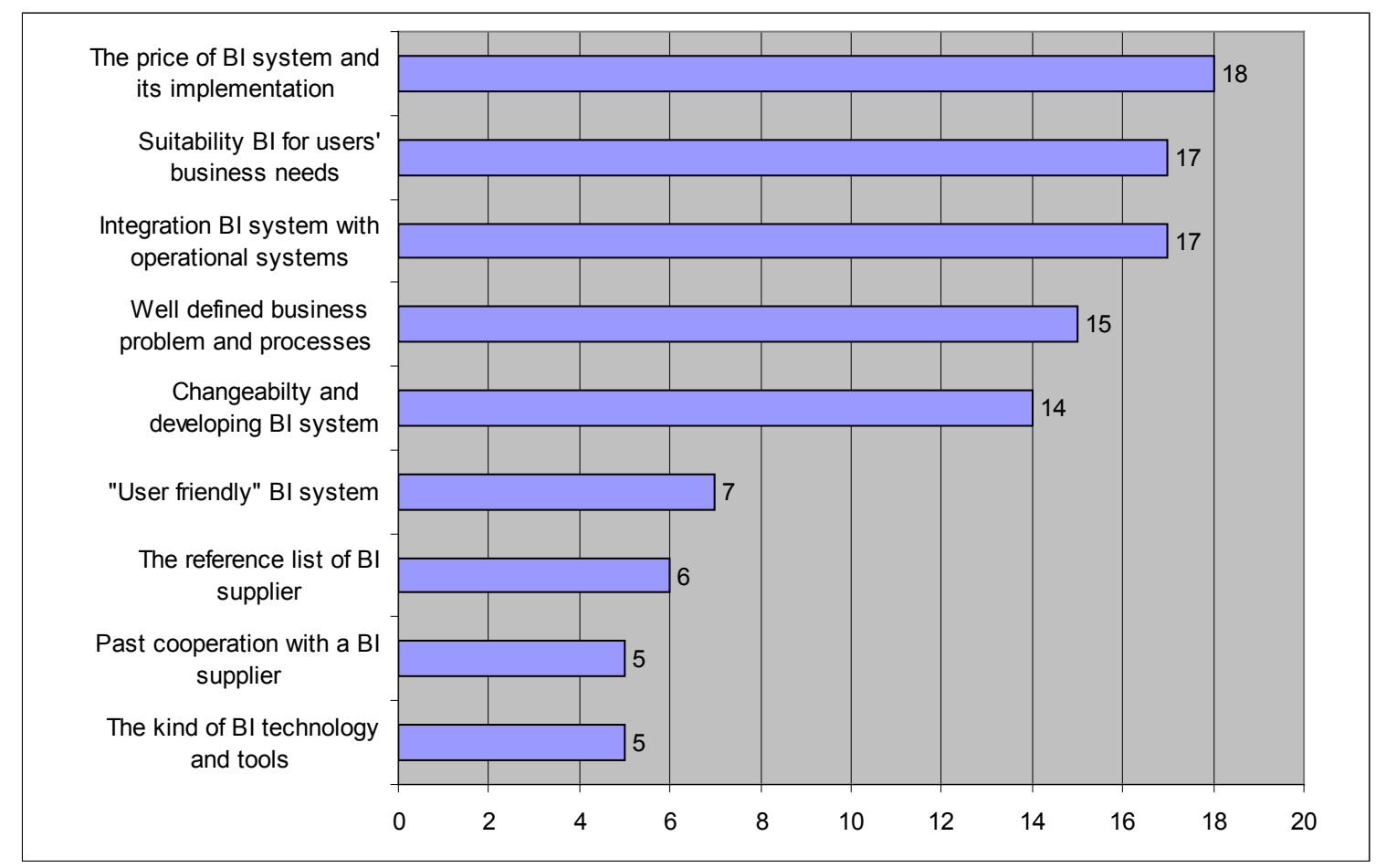

Figure 1: The determinants of BI system implementation in SMEs in Upper Silesia. 
terminates mentioned were suitability of BI for users' business needs (17 enterprises), integration of the operational system with BI systems (17 enterprises), well defined business problem and processes (15 enterprises), as well as changeability and development of the BI system (14 enterprises). Other important determinants of $\mathrm{BI}$ effective implementation mentioned by the surveyed enterprises are "user friendly" BI system, the reference lists of a BI supplier, past cooperation with a BI supplier, as well as the kind of BI technology and tools. The detailed results of the determinants governing the implementation of BI in SMEs are presented in Figure 1.

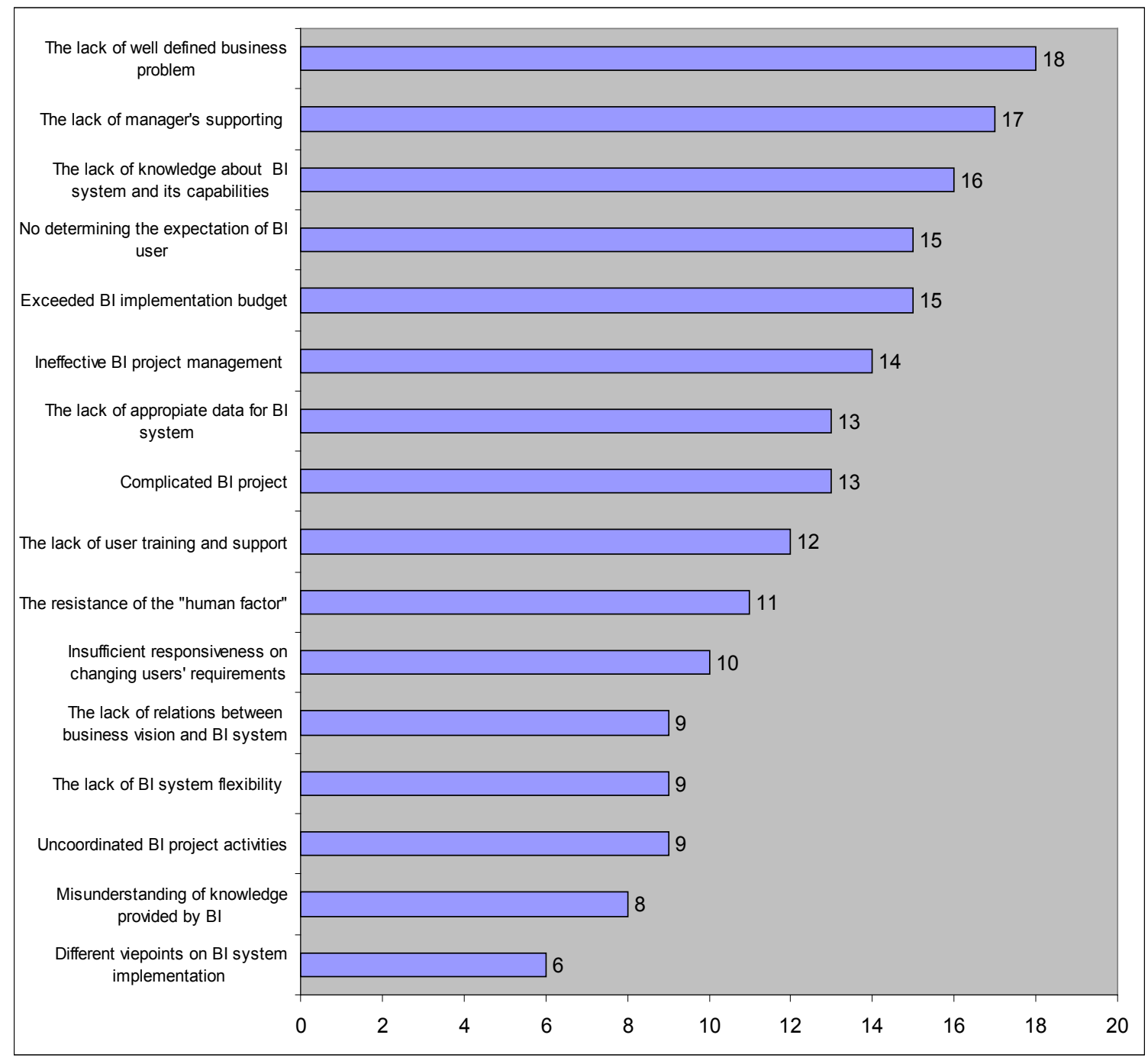

Figure 2: BI system implementation barriers in SMEs in Upper Silesia.

The biggest barriers that the respondents encountered during the implementation of BI systems have a business and organizational character. Among the business barriers, the most frequently mentioned were the lack of well defined business problems (18 enterprises), not determining the expectation of BI (15 enterprises), and the lack of relations between business and BI vision system ( 9 enterprises). Whereas as the key organizational barriers the studied enterprises enumerated were the lack of manager's support (17 enterprises), the lack of knowledge about the BI system and its capabilities (16 enterprises), exceeding the BI implementation budget (15 companies), ineffective BI project management (14 firms) and complicated BI project (13 enterprises), the lack of user training and support (12 enterprises), and the resistance of the "human factor" (11 enterprises). During the implementation of BI systems the enterprises had to overcome technolog- 
ical barriers, such as the lack of appropriate data for the BI system (13 enterprises) and the lack of BI system flexibility (9 enterprises). The detailed results of the barriers to BI systems implementation in SMEs are presented in Figure 2.

\section{Critical Success Factors for BI System Implementation in SMEs}

The knowledge about the most important determinants of and the barriers to BI systems implementation in SMEs obtained from the research has become the basis for identifying the most important CSFs for the BI system implementation in SMEs. The authors have also used their experience in the field of BI systems implementing. The critical thinking and inductive reasoning led us to indicate the three perspectives (categories) of CSFs. They are organization, process, and technology (Table 8). These perspectives result from the nature and determinants of barriers to the BI systems implementation. Within the frame of an individual perspective the critical success factors have been identified, accounting for the different determinants and barriers.

Table 8: CSFs of BI systems implementation in SMEs in Upper Silesia

\begin{tabular}{|l|l|l|}
\hline \multicolumn{1}{|c|}{ Organization Perspective } & \multicolumn{1}{|c|}{ Process Perspective } & \multicolumn{1}{c|}{ Technology Perspective } \\
\hline $\begin{array}{l}\text { Support from senior manage- } \\
\text { ment }\end{array}$ & $\begin{array}{l}\text { Effective change management } \\
\text { (e.g. willingness to accept } \\
\text { change of processes) }\end{array}$ & Data quality \\
\hline $\begin{array}{l}\text { Skilled (qualified) sufficient } \\
\text { staff/team/managers }\end{array}$ & $\begin{array}{l}\text { Well defined a business prob- } \\
\text { lem and processes }\end{array}$ & $\begin{array}{l}\text { Integration between BI system and } \\
\text { other systems (e.g. ERP) }\end{array}$ \\
\hline $\begin{array}{l}\text { Competent BI project manager } \\
\text { (leadership) }\end{array}$ & $\begin{array}{l}\text { Well defined users' expecta- } \\
\text { tion (information require- } \\
\text { ments) }\end{array}$ & Appropriate technology and tools \\
\hline $\begin{array}{l}\text { Past experience and coopera- } \\
\text { tion with a BI supplier }\end{array}$ & $\begin{array}{l}\text { Adjusting the BI solution to } \\
\text { users' business expectation } \\
\text { (requirements) }\end{array}$ & “User friendly" (usability) BI system \\
\hline Clear business vision and plan & $\begin{array}{l}\text { The lack of BI flexibility and respon- } \\
\text { siveness on users' requirements }\end{array}$ \\
\hline Adequate budget & & \\
\hline
\end{tabular}

The specified perspectives of CSFs and the CSFs identified within their framework were reexamined and re-assessed by the owner-managers, business analysts, and IT professionals from the surveyed enterprises. It turns out that the most important for BI systems implementation from an organization perspective are adequate budget (20 enterprises), support from senior management (18 enterprises), competent BI project manager (leadership) (18 enterprises) and skilled (qualified) sufficient staff / team / managers (17 enterprises) and clear business vision and a plan (17 enterprises). Regarded as less important are past experience and cooperation with a BI supplier (10 enterprises).

The most important elements of a process perspective were a well defined business problem and processes (20 enterprises) and well defined users' expectations (information requirements) (20 enterprises), and adjusting the BI solution to users' business expectations (requirements) (18 enterprises). Regarded as a little less important were effective change management (e.g., willingness to accept change in processes) (16 enterprises).

Regarded as the most important factor from a technology perspective was integration between the BI system and other systems, e.g. ERP, (20 enterprises). Subsequently were listed data quality (18 enterprises) and the flexibility and responsiveness of BI on users' requirements (17 enterprises). 
As slightly less important were appropriate technology and tools (15 enterprises) and "user friendly" (usability) BI system (13 enterprises).

The detailed results on the identified critical success factors are presented in Table 9.

Table 9: Impact CSFs on the success of the BI project in SMEs in Upper Silesia

\begin{tabular}{|c|c|c|}
\hline No & Critical Success Factor & $\begin{array}{c}\text { Impact on the success of } \\
\text { the BI project } \\
\text { (number of enterprises) }\end{array}$ \\
\hline \multicolumn{3}{|c|}{ Organization perspective } \\
\hline 1. & Adequate budget & 20 \\
\hline 2. & Support from senior management & 18 \\
\hline 3. & Competent BI project manager (leadership) & 18 \\
\hline 4. & Skilled (qualified) sufficient staff/team/managers & 17 \\
\hline 5. & Clear business vision and plan & 17 \\
\hline 6. & Past experience and cooperation with a BI supplier & 10 \\
\hline \multicolumn{3}{|c|}{ Process perspective } \\
\hline 7. & Well defined a business problem and processes & 20 \\
\hline 8. & $\begin{array}{l}\text { Well defined users' expectation (information require- } \\
\text { ments) }\end{array}$ & 20 \\
\hline 9. & $\begin{array}{l}\text { Adjusting the BI solution to users' business expecta- } \\
\text { tion (requirements) }\end{array}$ & 18 \\
\hline 10. & $\begin{array}{l}\text { Effective change management (e.g. willingness to ac- } \\
\text { cept change of processes) }\end{array}$ & 16 \\
\hline \multicolumn{3}{|c|}{ Technology perspective } \\
\hline 11. & $\begin{array}{l}\text { Integration between BI system and other systems (e.g. } \\
\text { ERP) }\end{array}$ & 20 \\
\hline 12. & Data quality & 18 \\
\hline 13. & $\begin{array}{l}\text { BI flexibility and responsiveness on users' require- } \\
\text { ments }\end{array}$ & 17 \\
\hline 14. & Appropriate technology and tools & 15 \\
\hline 15. & "User friendly" (usability) BI system & 13 \\
\hline
\end{tabular}

\section{Discussion}

The obtained research results show that CSFs of BI implementation in Upper Silesian SMEs in Poland can be classified from three perspectives: organization, process, technology. These perspectives are analogous to the CSFs perspectives demonstrated by Yeoh and Koroniom (2010). It results from our research as well as the research conducted by other authors (Imhof, 2004; Watson, 2004; Yeoh \& Koronios, 2010) that from an organization perspective for the implementation of BI the following are vital: clear business vision and plan, support from senior management, and competent BI project manager (leadership). From the process perspective the most important CSFs are effective change management, well defined a business problem and processes. Whereas from a technology perspective the most important are data quality and BI flexibility and responsiveness on users' requirements. 
However, there are also significant differences between our research and the research of other authors (Imhof, 2004; Watson, 2004; Yeoh \& Koronios, 2010). In Upper Silesia the following factors are important for SMEs:

- from organization perspective - adequate budget, competent BI project manager (leadership) and skilled (qualified) sufficient staff/team/managers, past experience and cooperation with a BI supplier;

- from process perspective - well defined users' expectations (information requirements) and adjusting the BI solution to users' business expectations (requirements); and

- from technology perspective - integration between BI system and other systems (e.g., ERP), appropriate technology and tools and "user friendly" (usability) BI system.

The differences in the results of the research are certainly caused by the fact that the research conducted by us referred to SMEs. The results clearly indicate poor skills and experience of employees and limited financial resources for selecting, adopting, and implementing BI systems. This, in turn, makes it more difficult for users to define their expectations well and to adjust the BI solution to the users' business expectation. SMEs require from BI systems a high level of usability, which allows for their more efficient utilization. Also highly important for BI implementation are the integration between the BI system and other systems (e.g., ERP) and the choice of appropriate technology and tools.

\section{Conclusions}

The research results indicate that the use of a BI system will result in a business success only if the BI users, on a regular basis, develop business and decision-making processes, recognize their needs, assist their modelling and oversee the completion of a project as well as actively participate in the implementation of new BI components. The knowledge and skills of a project team and BI systems users are of primary importance.

In summary, for a BI project's implementation to be successful and to bring tangible business benefits to SMEs in the future, it is necessary to meet some basic conditions:

- BI system must be a part of the company's business strategy. It must correspond to the real needs of users and support key processes and business decisions at all levels of management (strategic, tactical and operational). To do this the knowledge about the BI system opportunities in the context of business challenges becomes indispensable for an enterprise. A good understanding of decision-making processes is also required, because only then the BI system can be used effectively;

- Managing the BI system implementation ought to be centralized, but all of its prospective users should be involved in the implementation. Only such a situation will enable users to adapt the BI system functionality to the individual needs while ensuring the proper conduct and success of implementation;

- The implementation of the BI system requires appropriate knowledge and skills for the BI implementation. A competent project team, consisting of managers, employees and IT specialists, is essential;

- BI system implementation project must have a sponsor who is positioned in the organizational hierarchy as high as possible. Commitment of managers, especially of the board, in the process of choosing and implementing BI systems is required. This will ensure adequate resources and be a clear signal to employees that management attaches due importance to the project;

- BI system requires permanent development and adaptation to new challenges and expectations of an enterprise. The consequence of BI system non-development is its depreciation and withdrawal; 
- It is necessary for users to be able to use the BI system. This can be provided by staff training and a very high-friendliness of the system; and

- The cost of BI implementation must cover the costs of technology, but also account for measures to establish a project team, technical support, substantive support, change management, employees training as well as maintaining and developing the BI system in the future. Otherwise, the enterprise receives a powerful tool that no one will use.

The presented research and conclusions determine courses of action for SMEs and project teams who are challenged with the BI system implementation.

\section{References}

Amberg, M., Fischl, F., \& Wiener, M. (2005). Background of critical success factor research. Retrieved March 102011 from http://www.international-outsourcing.de/CSF Tool/docs/WorkingPaper_BackgroundCSF_Ambergetal._FINAL.pdf

Anandarajan, M. A., \& Srinivasan, C. A. (2004). Business intelligence techniques - A perspective from accounting and finance. Berlin: Springer.

Anthony, R. N., Dearden, J., \& Vancil, R. F. (1972). Management control systems. Homewood: Irwin.

Arendt, L. (2008). Barriers to ICT adoption in SMEs: How to bridge the digital divide? Journal of Systems and Information Technology, 10(2), 93-108.

Ariyachandra, T., \& Watson, H. (2006). Which data warehouse architecture is most successful? Business Intelligence Journal, 11(1).

Azvine, B., Cui, Z., Nauck, D. D., \& Majeed, B. (2006). Real time business intelligence for the adaptive enterprise. Proceedings of IEEE Joint Conference: the $8^{\text {th }}$ IEEE International Conference on Ecommerce Technology and the $3^{\text {rd }}$ IEEE International Conference on Enterprise Computing, ECommerce, and E-services (CEC/EEE'06). San Francisco, pp. 29-39.

Baaras, H., \& Kemper, H. G. (2008). Management support with structured and unstructured data - An integrated business intelligence framework. Information Systems Management, 25(2), 132-148.

Belassi, W., \& Tukel, O.I. (1996). A new framework for determining critical success/failure factors in project. International Journal of Project Management, 14(3), 141-151.

Bergeron, B. (2000). Regional business intelligence: The view from Canada. Journal of Information Science, 26(3), 153-160.

BI i controlling. Oprogramowanie dla biznesu (2011). Retrieved August 122011 from http://decyzje-it.pl/centrum-wiedzy/bi-i-controlling/oprogramowanie-bi.html

Chaudhary, S. (2004). Management factors for strategic BI success. In M. S. Raisinghani (Ed.), Business intelligence in digital economy. Opportunities, limitations and risks (pp. 191-206). Hershey: IGI Global.

Czinkota, M., Ronkainen, I. A., \& Moffett, M. H. (2008). Fundamentals of international business. New York: Wessex Publishing.

Daniel, D. R. (1961). Management information crises. Harvard Business Review, 39(5), 111-116.

Davenport, T. H., Harris, J. G., \& Morison, R. (2010). Analytics at work: Smarter decisions, better results. Boston: Harvard Business Press.

Eckerson, W. W. (2005). The keys to enterprise business intelligence: Critical success factors. The Data Warehousing Institute. Retrieved October 022011 from http://download.101com.com/pub/TDWI/Files/TDWIMonograph2-BO.pdf

Enzenhofer, W., \& Chroust, G. (2001). Best practice approaches in know-how and technology transfer methods for manufacturing SMEs. Proceedings of the 27th EUROMICRO Conference. CA: IEEE Computer Society, 279-286. 
Estrin, L., Foreman, J. T., \& Garcia, S. (2003). Overcoming barriers to technology adoption in small manufacturing enterprises (SMEs). Technical Report. Pittsburgh: Software Engineering Institute.

European Commission. (2010a). Annual report on EU small and medium-sized enterprises 2009. Retrieved March 02, 2011, from http://ec.europa.eu/enterprise/policies/sme/facts-figures- analysis/performancereview/pdf/dgentr_annual_report2010 100511.pdf

European Commission. (2010b). The small business act SBA. Factsheet Poland 2009. Retrieved March 02 $2011 \mathrm{from} \mathrm{http://ec.europa.eu/enterprise/policies/sme/facts-figures-analysis/performance-}$ review/pdf/final/sba fact_sheet_poland_en.pdf

European Commission. (2011). Small and medium enterprises. Retrieved March 022011 from http://epp.eurostat.ec.europa.eu/statistics_explained/index.php/Small_and_medium-sized_enterprises

European Union. (2003). Commission recommendation of 6 May 2003 concerning the definition of micro, small and medium-sized enterprises. Official Journal of the European of the European Union, L124, $36-41$.

Fortune, J., \& White, D. (2006). Framing of project critical success factors by a system model. International Journal of Project Management, 24, 53-65.

Fostering entrepreneurship and firm creation as a driver of growth in a global economy. (2004). Turkey: OECD.

Glancy, F. H., \& Yadav, S. B. (2011). Business intelligence conceptual model. International Journal of Business Intelligence Research, 2(2), 48-66.

Greene, F., \& Loughridge, B. (1996). Investigating the management information needs of academic heads of department: A critical success factor approach. Information Research, 1(3), 1-3.

Highlights from the 2003 Observatory. 2003 Observatory of the European SMEs. (2004). European Commission.

Hwang, H. G., Ku, C. Y., Yen, D. V., \& Cheng, C. C. (2004). Critical factors influencing the adoption of data warehouse technology: A study of the banking industry in Taiwan. Decision Support Systems, $37(1), 1-21$.

Imhoff, C. (2004). Business intelligence - Five factors for success. Retrieved March 10, 2011, from http://www.b-eye-network.co.uk/view/252

Inmon, W.H., Strauss, D., \& Neushloss, G. (2008). DW 2.0: The architecture for the next generation of data warehousing. Amsterdam: Elsevier Science.

Kwak, Y. H. (2002). Critical success factors in international development project management. Proceedings of 10th International Symposium Construction Innovation \& Global Competitiveness, Cincinnati, Ohio.

Leidecker, J., \& Bruno, A. (1987). CSF analysis and the strategy development process. In B. Taylor (Ed.), Strategic planning and management handbook (pp. 333-351). Van Nostrand: Rheinhold.

Luhn, H. P. (1958). A business intelligence system. IBM Journal of Research and Development, 2(4), 314319.

Moss, L., \& Atre, S. (2003). Business intelligence roadmap. The complete lifecycle for decision-support applications. Boston: Addison-Wesley.

Negash, S. (2004). Business intelligence. Communications of Association for Information Systems, 13, 177195.

Negash, S., \& Gray, P. (2008). Business intelligence. In F. Burstein, \& C. W. Holsapple (Eds.), Decision support systems (pp. 175-193). Berlin: Springer.

O’Brien, J. A., \& Marakas, G. M. (2007). Introduction to information systems. New York: McGrawHill.

Olszak, C. M., \& Ziemba, E. (2003). Business intelligence as a key to management of an enterprise. In E. Cohen, \& E. Boyd (Eds.), Proceedings of Informing Science and IT Education InSITE'2003. Santa Rosa: The Informing Science Institute. 
Olszak, C. M., \& Ziemba, E. (2004). Business intelligence systems as a new generation of decision support systems. In J.V. Carrasquero (Ed.), Proceedings of PISTA 2004, International Conference on Politics and Information Systems: Technologies and Applications. Orlando: The International Institute of Informatics and Systemics.

Olszak, C. M., \& Ziemba, E. (2006). Business intelligence systems in the holistic infrastructure development supporting decision-making in organizations. Interdisciplinary Journal of Information, Knowledge and Management, 1, 47-58.

Olszak, C. M., \& Ziemba, E. (2008). The conceptual model of a web learning portal for small and medium sized enterprises. The Journal of Issues in Informing Science and Information Technology, 5, 335-351.

Olszak, C. M., \& Ziemba, E. (2010a). Business performance management for competitive advantage in the information economy. Journal of Internet Banking and Commerce, 15(3), 93-104.

Olszak, C. M., \& Ziemba, E. (2010b). Knowledge management curriculum development: Linking with real business needs. Issues in Informing Science and Information Technology, 7, 235-248.

Olszak, C. M., \& Ziemba, E. (2011a). Communities of practice in knowledge management and organisational learning. In J. Yearwood, \& A. Stranieri (Eds.), Technologies for supporting reasoning communities and collaborative decision making: Cooperative approaches (pp. 76-93). Hershey: IGI Global.

Olszak, C. M., \& Ziemba, E. (2011b). The use of ICT for economic development in Silesian region in Poland. Interdisciplinary Journal of Information, Knowledge, and Management, 6, 197-216.

Power, D. J. (2007). A brief history of decision support systems. Retrieved August 122011 from http://dssresources.com/history/dsshistory.html

Reinschmidt, J., \& Francoise, A. (2000). Business intelligence certification guide. IBM, International Technical Support Organization.

Rockart, J. (1979). Chief executives define their own information needs. Harvard Business Review, March/April, 81-92.

Roztocki, N., \& Weistroffer, H. R. (2008). Information technology in transition economies. Journal of Global Information Technology Management, 11(4), 2-9.

Salmeron, J. L., \& Herrero, I. (2005). An AHP-based methodology to rank critical success factors of executive information systems. Computer Standards \& Interfaces, 28(1), 1-12.

Sauter, V. L. (2010). Decision support systems for business intelligence. New Jersey: Wiley.

Scholz, P., Schieder, C., Kurze, C., Gluchowski, P., \& Boehringer, M. (2010). Benefits and challenges of business intelligence adoption in small and medium-sized enterprises. In A. Trish, M. Turpin, \& J. P. van Deventer (Eds.), .Proceedings of 18th European Conference on Information Systems, ECIS2010.

Skowronek-Mielczarek, A. (2007). Małe i średnie przedsiębiorstwa. Źródła finansowania. Warszawa: C.H. Beck.

The Standish Group International Inc. (2001). Extreme chaos. Retrieved August 122011 from http://standishgroup.com/sample_research/extreme_chaos.pdf

Stimson, R. J., Stough, R. R., \& Roberts, B. H. (2006). Regional economic development-Analysis and planning strategy. Leipzig: Springer.

Thong, J. Y. L., \& Yap, C. S. (1997). Effects of resource constraints on small business. Proceedings of the International Working Conference on Diffusion, Adoption and Implementation of Information Technology. London: Chapman \& Hall, 191-206.

Turban, E., McLean, E., \& Wetherbe, J. (2001). Information technology for management. Improving quality and productivity. New Jersey: John Wiley \& Sons.

Watson J. (2010). SME performance: Separating myth from reality. Cheltenham: Edward Elgar Publishing.

Watson H. J., Fuller C., \&. Ariyachandra, T (2004). Data warehouse governance: Best practices at Blue Cross and Blue Shield of North Carolina. Decision Support Systems, 38 (3), 435-450. 
Wells, D. (2003). Ten best practices in business intelligence and data warehousing. Retrieved August 12 2011 from https://www.tdwi.org/Publications/display.aspx?id=6638\&t=y

Wells, D. (2008). Business analytics - Getting the point. Retrieved August 122011 from http://b-eyenetwork.com/view/7133

Wielicki, T., \& Arendt, L. (2010). A knowledge-driven shift in perception of ICT implementation barriers: Comparative study of US and European SMEs. Journal of Information Science, 36(2), 162-174.

Williams, S., \& Williams, N. (2007). Critical success factors for establishing and managing a BI program. Gaithersburg: Decision Path Consulting. Retrieved August 122011 from http://www.decisionpath.com:8180/docs_downloads/5\%20Critical\%20Success $\% 20$ Factors $\% 20$ \%20For\%20Establishing\%20and\%20Managing $\% 20 \mathrm{a} \% 20 \mathrm{BI} \% 20$ Program.pdf

Wise, L. (2007). Five steps to business intelligence project success. Retrieved October 122011 from http://www.technologyevaluation.com/Research/ResearchHighlights/BusinessIntelligence/2009/06/res earch_notes/TU_BI_ER_LW_06 19 09 1.asp

Wixom, B. H., \& Watson, H. J. (2001). An empirical investigation of the factors affecting data warehousing success. MIS Quarterly, 25(1), 17-41.

Wixom, B. H., \& Watson, H. J. (2010). The BI-based organization. International Journal of Business Intelligence Research, 1, 13-28.

Yeoh, W., \& Koronios, A. (2010). Critical success factors for Business Intelligence systems. Journal of Computer Information Systems, 50(3), 23-32.

\section{Biographies}

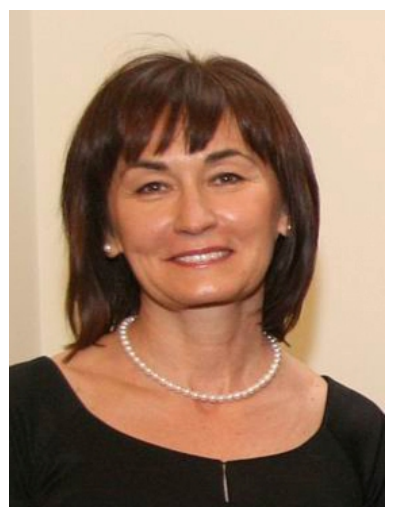

Celina M. Olszak is a Professor of Management Information Systems at University of Economics in Katowice, Poland. She is Chair of the Department of Business Informatics and Vice-Dean in Charge of Research at the Faculty of Economics. She was scholarship holder at Swiss Federal Institute of Technology in Zurich, Switzerland and scholarship holder of Deutsche Akademische Austausch Dienst at Trier University in Germany. She has published numerous articles in the areas of information systems, decision support systems, systems development strategies. Her current research interests include knowledge management, Business Intelligence Systems, e-business and information society. She is a member of Polish Academy of Sciences and Informing Science Institute in California, USA.

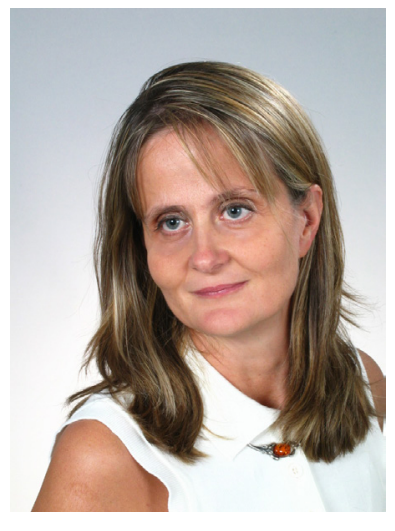

Ewa Ziemba is an associate Professor of Management Information Systems at the University of Economics in Katowice, Poland. Her research interests include information systems for knowledge management, e-business systems and information society. She has more than 150 refereed publications as books, journal papers and papers in conference proceedings. She has participated in several Polish and European research projects. Her current research project deals with designing a system approach to sustainable development of the information society. Her academic qualifications have been combined with practical experience - she has been working as the IT Project Manager for over ten years. Furthermore, she is a member of Polish Academy of Sciences and Informing Science Institute in California, USA. 